Tropical Journal of Pharmaceutical Research August 2020; 19 (8): 1669-1676

ISSN: $1596-5996$ (print); 1596-9827 (electronic)

(C) Pharmacotherapy Group, Faculty of Pharmacy, University of Benin, Benin City, 300001 Nigeria.

Original Research Article

http://dx.doi.org/10.4314/tjpr.v19i8.15

\title{
Aged garlic extract potentiates doxorubicin cytotoxicity in human breast cancer cells
}

\author{
Huda Mohammed Alkreathy ${ }^{1}$, Noura Farraj AIShehri ${ }^{1}$, Fatemah Omer Kamel ${ }^{1}$, \\ Ahmed Khalaf Alghamdi ${ }^{3}$, Ahmed Esmat ${ }^{1,2}$, Shahid Karim ${ }^{1 *}$ \\ ${ }^{1}$ Department of Pharmacology, Faculty of Medicine, King Abdulaziz University, Jeddah, Kingdom of Saudi Arabia, ${ }^{2}$ Department \\ of Pharmacology \& Toxicology, Faculty of Pharmacy, Ain Shams University, Cairo 11566, Egypt, ${ }^{3}$ College of Medicine- King \\ Saud bin Abdulaziz University for Health Sciences, Jeddah, Saudi Arabia
}

*For correspondence: Email: shahid.karim@yahoo.co.in

Sent for review: 24 February 2020

Revised accepted: 15 July 2020

\begin{abstract}
Purpose: To investigate the potential chemo-sensitizing effect of aged garlic extract (AGE) on doxorubicin (DOX) in breast cancer cells (MCF-7), and the possible underlying mechanisms.

Methods: Human breast cancer cell line (MCF-7) was treated with AGE and DOX. The cytotoxic effects of $A G E$ and DOX were investigated via cell cycle analysis and apoptosis induction, using flow cytometry. Mechanistic studies involved the determination of cellular uptake of DOX and p-glycoprotein (P-gp) activity.

Results: Combined treatment of MCF7 cells with AGE and DOX produced no significant effect at AGE dose of $10 \mathrm{mg} / \mathrm{mL}$. However, co-treatment with AGE at doses of 50 and $93 \mathrm{mg} / \mathrm{mL}$ enhanced the cytotoxicity of DOX on MCF-7 cells, with IC $C_{50}$ values of 0.962 and $0.999 \mu M$, respectively, when compared with $1.85 \mu M$ DOX alone. Moreover, Annexin V-FITC and PI techniques showed that AGE significantly increased percentage of cells in late apoptosis. Besides, AGE-DOX treatment significantly increased cellular uptake of DOX and inhibited P-gp activity, when compared with DOX alone $(p<0.05)$. Conclusion: AGE enhances the cytotoxic effect of DOX on MCF-7 cells, most likely due to cell cycle distribution, stimulation of apoptosis, increased uptake of DOX by MCF7, and inhibition of P-gp activity.
\end{abstract}

Keywords: Aged garlic extract, Doxorubicin, Breast cancer, MCF-7 cell line, P-glycoprotein, Apoptosis, Cell cycle

This is an Open Access article that uses a fund-ing model which does not charge readers or their institutions for access and distributed under the terms of the Creative Commons Attribution License (http://creativecommons.org/licenses/by/4.0) and the Budapest Open Access Initiative (http://www.budapestopenaccessinitiative.org/read), which permit unrestricted use, distribution, and reproduction in any medium, provided the original work is properly credited.

Tropical Journal of Pharmaceutical Research is indexed by Science Citation Index (SciSearch), Scopus, International Pharmaceutical Abstract, Chemical Abstracts, Embase, Index Copernicus, EBSCO, African Index Medicus, JournalSeek, Journal Citation Reports/Science Edition, Directory of Open Access Journals (DOAJ), African Journal Online, Bioline International, Open-J-Gate and Pharmacy Abstracts

\section{INTRODUCTION}

Breast cancer $(B C)$ is the most prevalent malignancy in women worldwide. The worldwide incidence of the $B C$ is on the rise [1]. The incidence of $B C$ varies with geographical location, with the highest cases in advanced countries, and lower cases in developing countries in Asia, the Middle East, and Africa [2] The first line chemotherapeutic drug used for BC is doxorubicin (DOX) which is a broad spectrum anthracycline antibiotic against lymphomas, leukemia, and solid tumors [3]. However, DOX is associated with cardiotoxic side effects which limit its use. In an attempt to develop a new therapeutic combination so as to maximize the 
chemotherapeutic effects for DOX at low doses and minimize its adverse effects, a diversity of tactics have been investigated.

It is worth noting that herbal medicines have been used for long in the prevention and treatment of various diseases such as heart disease, cancer and obesity. Garlic (Allium sativum) is a member of vegetables belonging to the genus Allium. Organosulfur compounds are responsible for the health benefits derivable from garlic consumption. Recently, the therapeutic benefits of garlic in diverse biosystems has been discovered. These benefits include anti-oxidant, anti-tumorigenic and cardio-protective effects [4,5]. Aged garlic extract (AGE) is a liquid prepared through prolonged ethanol extraction of fresh garlic for up to 20 months at room temperature [6]. The extract does not cause adverse events, and it has been confirmed to be safe in preclinical trials [7]. Compared with other garlic products, AGE is the most useful garlic preparation used as an antioxidant [5]. It exerts cytotoxic properties in a wide variety of tumor cells, including gastric and colon cancer cells [8]. In addition, it has been reported that $A G E$ exerted protective effects against DOX-induced cardiotoxicity in rats [4].

Human breast cancer cell lines are fundamental tools for studying BC at the molecular level. They could be utilized as in vitro models in laboratory cancer research. The MCF7 cell line was isolated by Dr. Soule and his colleagues in 1973 from the pleural effusion of elderly patient with metastatic breast carcinoma at the Michigan Cancer Foundation. This cell line is accepted globally as an appropriate model for use in the evaluation of the anticancer effects of drugs [9]. The current study was designed to determine the potential chemo-sensitizing effect of AGE on the cytotoxicity of DOX against MCF-7, as well as the possible underlying mechanisms, with respect to cell cycle phase distribution, apoptosis induction, DOX cellular uptake and Pglycoprotein activity.

\section{EXPERIMENTAL}

\section{Chemicals}

Doxorubicin hydrochloride (DOX), phosphate buffered saline (PBS), culture medium (RPMI 1640), fetal bovine serum (FBS), trypsin/EDTA mixture, penicillin G, streptomycin and rhodaminse 123 were purchased from Merck (St. Louis, MO, USA). Aged garlic extract (Kyolic, AGE) was kindly provided by Wakunaga of America (Mission Viejo, CA).

\section{Cell culture and measurement of cytotoxicity}

Human Breast Cancer cell line (MCF-7) was obtained from National Cancer Institute $(\mathrm{NCl})$, Cairo University, Egypt. The cells were cultured in RPMI 1640 supplemented with $10 \%$ FBS, streptomycin $(50 \mu \mathrm{g} / \mathrm{ml})$ and penicillin $(100 \mathrm{U} / \mathrm{mL})$ at $37{ }^{\circ} \mathrm{C}$ in a $5 \% \mathrm{CO}_{2}$ incubator. Cytotoxicity was determined using SRB assay according to the method of Skehan et al [10]. The cells were simultaneously incubated with different concentrations of DOX and AGE i.e. DOX at concentrations of $0.1,1,10$ and $100 \mu \mathrm{M}$; and AGE at concentrations of 10,50 , and $93 \mathrm{mg} / \mathrm{mL}$, with 3 wells for each concentration. After $48 \mathrm{~h}$, cell monolayers were fixed with trichloroacetic acid $(10 \% \mathrm{w} / \mathrm{v})$ and stained with $0.4 \%$ SRB using Cell Cytotoxicity Assay Kits (Aldrich Chem. Corp., USA), in line with the manufacturer's instructions. Optical density was read at $490 \mathrm{~nm}$ in a microplate reader (Model ELx808, BioTek, U.S.A.).

\section{Cell cycle analysis}

The MCF7 cells were seeded in 6-well plates at a density of $2 \times 10^{5}$ cells/well in RPMI 1640 for 24 h. Thereafter, the cells were incubated with DOX $(1.85 \mu \mathrm{M})$ alone and/or simultaneously with AGE (50 and $93 \mathrm{mg} / \mathrm{mL}$ ). After $48 \mathrm{~h}$, the cells were washed thrice with PBS, followed by harvesting via trypsinization. For cell cycle analysis, the pellet was re-suspended at cell density of $1 \times 10^{6}$ cells $/ \mathrm{mL}$ in the assay buffer, and processed according to the instructions in the cell cycle determination kit (Cayman Chemical Company, USA). Cell cycle analysis was carried out using flow cytometry (Becton Dickinson (BD) FACS Caliber, U.S.A) [11].

\section{Determination of apoptosis}

Apoptotic and necrotic cells were distinguished and investigated using flow cytometry based on the assay of Van Engeland et al [12], using Annexin V-FITC apoptosis detection kit obtained from Aldrich Chem. Corp., USA. The cells were suspended in $200 \mu \mathrm{L}$ of Annexin V incubation reagent prepared (for each sample) by mixing $\mathrm{PI}$, binding buffer 10X and Annexin V-FITC in deionized water. The mixture was incubated in the dark at $23^{\circ} \mathrm{C}$ for $15 \mathrm{~min}$, followed by addition of $400 \mu \mathrm{L}$ of binding buffer to each sample, and flow cytometric analysis (NAVIOS Beckman Coulter, U.S.A.).

\section{Assay of cellular uptake of DOX}

After cell treatment and trypsinization, $1 \times 10^{6}$ cells were digested by resuspending them in 2 
$\mathrm{mL}$ of $1: 1(\mathrm{v}: \mathrm{v})$ mixture of ethanol and $0.3 \mathrm{M} \mathrm{HCl}$ for $24 \mathrm{~h}$ at $70^{\circ} \mathrm{C}$. Then, $3 \mathrm{~mL}$ of PBS was added to each sample. In a clear, black flat-bottom 96well plate, $100 \mu \mathrm{L}$ of lysed cells was added to each well. The lysed cells were analyzed using a spectrofluorometer (Synergy HT microplate reader, BioTek, USA) at optimal excitation and emission wavelengths of 485 and $590 \mathrm{~nm}$, respectively $[13,14]$.

\section{Assay of P-gp activity}

Following 24-hour cell seeding, $100 \mu \mathrm{L}$ of working solution of Rhodamine 123 (2.62 $\mu \mathrm{M})$ was added per well and the wells were kept in a $\mathrm{CO}_{2}$ incubator at $37^{\circ} \mathrm{C}$ in the dark for $30 \mathrm{~min}$. Then, the cells were treated as stated previously. Following trypsinization, the cells were washed once with ice-cold PBS. For P-glycoprotein assay, one million cells were suspended in $1 \mathrm{~mL}$ of PBS, with shaking. The lysed cells were analyzed using a spectrofluorometer (Synergy HT microplate reader, BioTek, USA) at wavelength range of 485 - 590 [15-17].

\section{Statistical analysis}

Data are presented as mean \pm standard error of the mean (SEM). Statistical analysis was done using one-way analysis of variance, and then Tukey's post-hoc test. All analyses were carried out with InStat version 3 software package. Graphs were drawn by means of GraphPad Prism (ISI ${ }^{\circledR}$ software, USA) version 5 software. Values of $p<0.05$ were used as criteria for statistical significance of differences.

\section{RESULTS}

\section{Effect of DOX and AGE on cytotoxicity of MCF-7 cells}

Figure 1 shows the effect of DOX (with or without simultaneous treatment with different concentrations of AGE) on the growth of MCF-7 cell line. Treatment with DOX alone at a dose of $1 \mu \mathrm{g} / \mathrm{mL}$ resulted in $\mathrm{IC}_{50}$ value of $1.85 \mu \mathrm{M}$. Interestingly, co-treatment of the cells with AGE $(10 \mathrm{mg} / \mathrm{mL})$ decreased the sensitivity to the cells to the cytotoxic effect of DOX, with $\mathrm{IC}_{50}$ elevated to $9.46 \mu \mathrm{M}$.

In contrast, co-treatment with higher concentrations of AGE (50 and $93 \mathrm{mg} / \mathrm{mL}$ ) significantly increased the sensitivity of MCF-7 cells to DOX, with $\mathrm{IC}_{50}$ values of 0.962 and 0.99 $\mu \mathrm{M}$, respectively, without any obvious difference in cytotoxicity between the two higher concentrations.



Figure 1: Effect of DOX and/or AGE treatment on the viability of MCF-7 cells. Cell survival was determined after $48 \mathrm{~h}$ of exposure to the drugs. Data are presented as mean \pm SEM of 3 independent experiments. (A) $\mathrm{IC}_{50}$ of DOX alone, (B) $\mathrm{IC}_{50}$ of DOX $(1.85 \mu \mathrm{M})+$ AGE $(10 \mathrm{mg} / \mathrm{mL}) ;(C) \mathrm{IC}_{50}$ of DOX $(1.85$ $\mu \mathrm{M})+\mathrm{AGE}(50 \mathrm{mg} / \mathrm{mL}) ;(\mathrm{D}) \mathrm{IC}_{50}$ of DOX $(1.85 \mu \mathrm{M})+$ AGE $(93 \mathrm{mg} / \mathrm{mL})$

\section{Cell cycle analysis}

As shown in Figure 2 and Table 1, treatment with AGE (50 and $93 \mathrm{mg} / \mathrm{mL}$ ) showed significant increase in apoptosis (9.87 and $15.13 \%$, respectively), when compared to apoptotic cells in the control (7.03 \%). Moreover, the higher AGE dose $(93 \mathrm{mg} / \mathrm{mL})$ resulted in a significant decrease in the proportion of cells in the $S$ and G2/M phases (23.53 and $11.87 \%$, respectively), when compared to cells in the $S$ and $\mathrm{G} 2 / \mathrm{M}$ phases in the control group (28.83 and $17.97 \%$, respectively).

Combination treatment with $\operatorname{DOX}(1.85 \mu \mathrm{M})$ and AGE (50 and $93 \mathrm{mg} / \mathrm{mL}$ ) produced significant increases in apoptosis (16.37 and $23.37 \%$, respectively), when compared with control (7.03 $\%)$ and DOX alone (12.5\%). Furthermore, combination treatment with DOX $(1.85 \mu \mathrm{M})$ and AGE $(93 \mathrm{mg} / \mathrm{mL})$ resulted in significant decrease in cells arrested in $\mathrm{G} 1 / \mathrm{G} 0$ phase of the cell cycle (24.07\%), when compared with control (41.83 $\%)$ and DOX alone (38.7 \%). Moreover, this combination produced significant decrease in cells in S phase $(23.87 \%)$, when compared with DOX alone (30.47\%). On the other hand, it resulted in significant increase in cells accumulated in G2/M phase of the cell cycle (20.73\%), when compared with DOX alone $(14.43 \%)$. Interestingly, the combination of DOX $(1.85 \mu \mathrm{M})$ and AGE (50 mg/mL) significantly increased apoptotic cells by more than two folds, while combination of DOX $(1.85 \mu \mathrm{M})$ and AGE $(93 \mathrm{mg} / \mathrm{mL}$ ) significantly increased apoptotic cells 
by more than three folds, when compared to the corresponding controls.

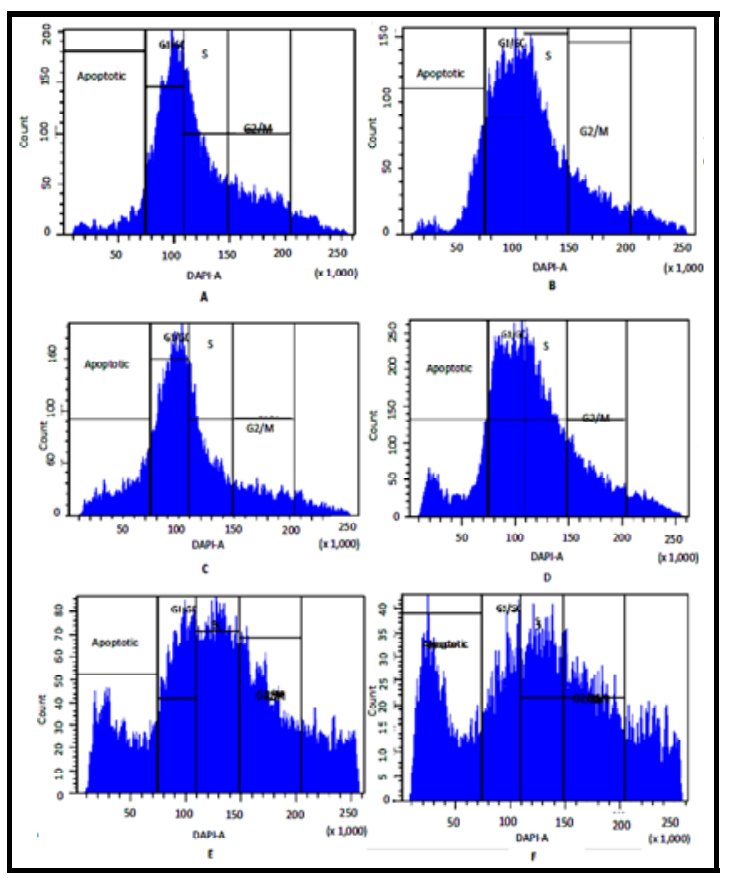

Figure 2: Effect of DOX and /or AGE treatment on cell cycle phase distribution of parent MCF-7 cells. Cell cycle distribution was analysed after the cells were exposed to the drugs for $48 \mathrm{~h}$ and stained with PI. (A) Control, (B) cells treated with DOX $(1.85 \mu \mathrm{M}),(\mathrm{C})$ cells treated with AGE $(50 \mathrm{mg} / \mathrm{mL})$, (D) cells treated with DOX $(1.85 \mu \mathrm{M})$ plus AGE $(50 \mathrm{mg} / \mathrm{mL})$; (E) cells treated with AGE $(93 \mathrm{mg} / \mathrm{mL})$, and $(F)$ cells treated with DOX $(1.85 \mu \mathrm{M})$ plus AGE $(93 \mathrm{mg} / \mathrm{mL})$.

\section{Effect of treatments on apoptosis}

Figure 3 shows the distribution of cells in each quadrant according to necrosis, late apoptosis, live cells, and early apoptosis (Annexin Vpositive cells). Cell treatments with DOX and/or AGE were carried out in a way similar to that used in cell cycle analysis. As shown in Figure 3, the most prominent effect was increase in percentage of cells in late apoptosis quadrant.
The percentages of live and late apoptotic cells after treatments are shown in Table 2. The percentage of live cells was significantly decreased by more than $50 \%$ after treatment with DOX $(1.85 \mu \mathrm{M})$, when compared with control cells. The effect of AGE alone $(50 \mathrm{mg} / \mathrm{mL})$ was weaker than that of DOX: although it was able to significantly reduce live cells, it did so at a lower extent than DOX. However, more obvious effects were observed after co-treatment with DOX (1.85 $\mu \mathrm{M})$ and $\mathrm{AGE}(50 \mathrm{mg} / \mathrm{mL})$, where live cells decreased to almost one-third of the control value. Amazingly, combination treatment of DOX $(1.85 \mu \mathrm{M})$ and AGE (93 $\mathrm{mg} / \mathrm{mL})$ produced very strong effect.

The percentage increase in late apoptotic cells was dramatic after treatment with $1.85 \mu \mathrm{M}$ DOX (45\%) or AGE at doses of 50 and $93 \mathrm{mg} / \mathrm{mL}$ (19.73 and $48.5 \%$, respectively), when compared to the control $(7.2 \%)$.

These findings confirmed that apoptosis was significantly elevated after treatment with DOX. Again, co-treatment with $\operatorname{DOX}(1.85 \mu \mathrm{M})$ and AGE $(50 \mathrm{mg} / \mathrm{ml})$ was more effective in increasing percentage of apoptotic cells than treatment with DOX alone. In addition, cell treatment with AGE alone $(93 \mathrm{mg} / \mathrm{mL}$ ) resulted in late apoptosis in almost half of the cell population. Furthermore, co-treatment with DOX and AGE (93 $\mathrm{mg} / \mathrm{mL}$ ) had very potent effect, being able to induce apoptosis in more than 90 $\%$ of the cell population.

\section{Effect of treatments on DOX cellular uptake and p-gp activity}

To determine the sensitivity of MCF-7 cells to the growth-inhibitory effect of DOX against MCF-7 cells, intracellular DOX level per $10^{6}$ cells was measured. The cells were treated with DOX $(1.85 \mu \mathrm{M})$ in the presence or absence of AGE (50 and $93 \mathrm{mg} / \mathrm{mL}$ ).

Table 1: Effect of AGE and/or DOX treatment on cell cycle phase distribution of MCF-7 cells

\begin{tabular}{lcccc}
\hline Treatment & Apoptotic & G0/G1 & S & G2/M \\
\hline Control & $7.03 \pm 0.4$ & $41.83 \pm 1.15$ & $28.83 \pm 1.53$ & $17.97 \pm 0.4$ \\
DOX $(1.85 \mu \mathrm{M})$ & $12.5^{\mathrm{a}} \pm 0.66$ & $38.7 \pm 1.73$ & $30.47 \pm 1.11$ & $14.43 \pm 1.55$ \\
AGE $(50 \mathrm{mg} / \mathrm{mL})$ & $9.87^{\mathrm{a}} \pm 0.67$ & $36.3 \pm 4.88$ & $32.63 \pm 4.6$ & $15.87 \pm 1.16$ \\
DOX $(1.85 \mu \mathrm{M})+$ AGE & $16.37^{\mathrm{a}, \mathrm{b}} \pm 0.96$ & $32.53^{\mathrm{a}} \pm 3.1$ & $27.5 \pm 1.04$ & $17.83 \pm 2.68$ \\
$(50 \mathrm{mg} / \mathrm{mL})$ & $15.13^{\mathrm{a}} \pm 0.35$ & $46.8 \pm 2.25$ & $23.53^{\mathrm{b}} \pm 0.97$ & $11.87^{\mathrm{a}} \pm 0.45$ \\
AGE $(93 \mathrm{mg} / \mathrm{mL})$ & $23.37^{\mathrm{a}, \mathrm{b}} \pm 1.96$ & $24.07^{\mathrm{a}, \mathrm{b}} \pm 1.76$ & $23.87^{\mathrm{b}} \pm 0.75$ & $20.73^{\mathrm{b}} \pm 3.35$ \\
DOX $(1.85 \mu \mathrm{M})+$ AGE & &
\end{tabular}

Data are presented as mean \pm S.E.M of three independent experiments $(n=3)$. Statistical analyses were performed using one-way ANOVA, followed by Tukey's post-hoc test. ${ }^{a} p<0.05$, compared with corresponding control; ${ }^{\mathbf{b}} p<0.05$, compared with corresponding DOX-alone treatment 


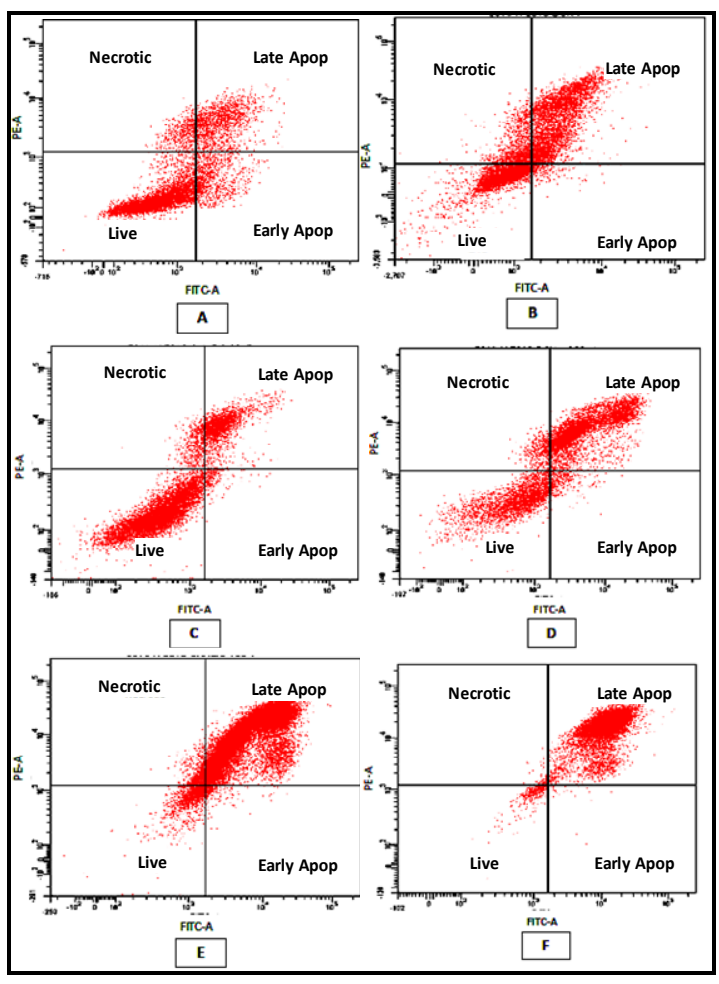

Figure 3: Effect of AGE and /or DOX treatment on induction of apoptosis in MCF-7 cells. Apoptosis was analysed after the cells were exposed to the drugs for $48 \mathrm{~h}$ and stained with Annexin V-FITC and PI. (A) control, (B) cells treated with DOX $(1.85 \mu \mathrm{M}),(\mathrm{C})$ cells treated with AGE $(50 \mathrm{mg} / \mathrm{mL})$, (D) cells treated with AGE $(50 \mathrm{mg} / \mathrm{mL})$ plus DOX $(1.85 \mu \mathrm{M}),(\mathrm{E})$ cells treated with AGE $(93 \mathrm{mg} / \mathrm{mL})$, and $(F)$ cells treated with AGE $(93 \mathrm{mg} / \mathrm{mL})$ plus DOX $(1.85 \mu \mathrm{M})$

Figure $4 \mathrm{~A}$ shows that DOX cellular uptake $/ 10^{6}$ cells was increased significantly by more than 2 folds on co-treatment with AGE (50 mg/mL). Moreover, co-treatment with DOX and AGE (93 $\mathrm{mg} / \mathrm{mL}$ ) caused about 4-fold increase in DOX uptake by MCF-7 cells. In order to explain the higher cellular uptake of DOX in the presence of AGE, P-gp activity was assayed via determination of the accumulation of Rh123 in MCF7 cells. As indicated in Figure 4 B, Rh123 accumulation was markedly increased in MCF7/DOX cells in the presence of AGE, when compared to MCF-7/DOX cells. This effect was concentration-dependent, since AGE at a concentration of $50 \mathrm{mg} / \mathrm{mL}$, increased intracellular Rh123 by about 3.8 folds, while AGE at a concentration of $100 \mathrm{mg} / \mathrm{mL}$, had a more prominent effect, being able to cause $>6$-fold increase of Rh123 accumulation, when compared to the control value. These results suggest that P-gp active outward transport was inhibited by $A G E$.

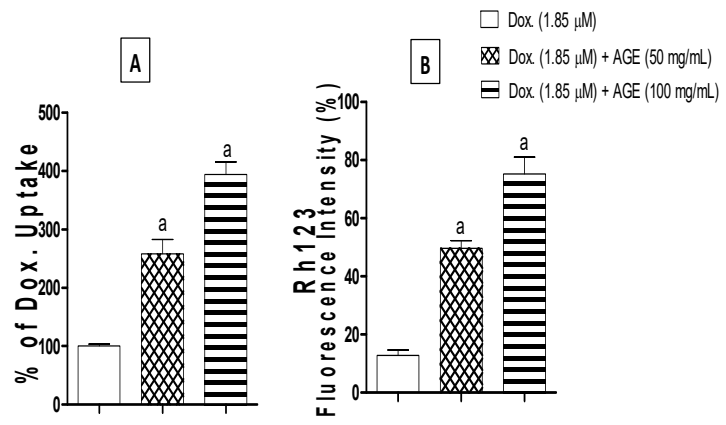

Figure 4: Effect of AGE co-treatment on: (A) cellular uptake of DOX $/ 10^{6}$ MCF-7 cells, (B) P-gp activity, as indicated by intracellular accumulation of $\mathrm{Rh} 123 / 10^{6}$ MCF-7 cells. Both assays were carried out spectrofluorometrically. Data are displayed as mean \pm S.E.M of 3 independent experiments $(n=3)$. Statistical analyses were performed using one-way ANOVA, followed by Tukey's post-hoc test; a $p<0.05$, compared to DOX

\section{DISCUSSION}

Doxorubicin (DOX) is widely used in cancer therapy for human neoplasms. The clinical benefits of DOX are limited by cell resistance and serious adverse effects, specifically dose-related and cumulative cardiotoxicity [18]. Chemosensitization is a strategy for overcoming chemoresistance. A diversity of tactics has been employed to enhance the therapeutic effects of chemotherapeutic agents, while decreasing their toxicities. Among the potential chemosensitizers is the natural product AGE, which exerts chemopreventive and cytotoxic effects.

Table 2: Effect of DOX and /or AGE treatment on live cells and late apoptosis in MCF-7 cells

\begin{tabular}{lcc}
\hline Treatment & Live cells & Late apoptosis \\
\hline Control & $83.87 \pm 1.45$ & $7.2 \pm 0.71$ \\
DOX $(1.85 \mu \mathrm{M})$ & $39.17^{\mathrm{a}} \pm 2.53$ & $45^{\mathrm{a}} \pm 2.7$ \\
AGE $(50 \mathrm{mg} / \mathrm{mL})$ & $71.17^{\mathrm{a}, \mathrm{b}} \pm 1.68$ & $19.73^{\mathrm{a}, \mathrm{b}} \pm 1.86$ \\
DOX $(1.85 \mu \mathrm{M})+$ AGE $(50 \mathrm{mg} / \mathrm{mL})$ & $33.1^{\mathrm{a}, \mathrm{b}} \pm 3.3$ & $56^{\mathrm{a}, \mathrm{b}} \pm 2.91$ \\
AGE $(93 \mathrm{mg} / \mathrm{mL})$ & $36.3^{\mathrm{a}} \pm 1.6$ & $48.5^{\mathrm{a}} \pm 1.57$ \\
DOX $(1.85 \mu \mathrm{M})+$ AGE $(93 \mathrm{mg} / \mathrm{mL})$ & $3.4^{\mathrm{a}, \mathrm{b}} \pm 0.26$ & $91.5^{\mathrm{a}, \mathrm{b}} \pm 1.99$ \\
\hline
\end{tabular}

Data are shown as mean \pm SEM $(n=3)$. Statistical analyses were performed using one-way ANOVA, followed by Tukey's post-hoc test. a $p<0.05$, compared to control; ${ }^{b} p<0.05$, compared to corresponding DOX-alone treatment 
This study was aimed at investigating the potential chemo-sensitizing effect of AGE on DOX against the growth of MCF-7 cells, as well as the likely underlying mechanisms with regard to DOX cytotoxicity, cell cycle phase distribution, apoptosis induction, DOX cellular uptake and P. glycoprotein activity. Treatment of MCF-7 cells with different concentrations of DOX alone was cytotoxic to the cells, with $\mathrm{IC}_{50}$ of $1.85 \mu \mathrm{M}$ (equivalent to $1 \mu \mathrm{g} / \mathrm{mL}$ ). Similar findings were reported by Buranrat and co-workers who exposed MCF-7 cells to DOX and determined their viability using SRB assay [19]. Their results demonstrated that cell growth was inhibited after $48 \mathrm{~h}$ of treatment, with $\mathrm{IC}_{50}$ value of $1.8 \pm 0.1 \mu \mathrm{M}$ at $48 \mathrm{~h}$.

In the present study, DOX cytotoxicity was established in the results of cell cycle distribution and induction of apoptosis, where DOX (1.85 $\mu \mathrm{M})$ caused a significant increase in apoptotic cells, significant decrease in the percentage of live MCF-7 cells, and marked increase in the extent of apoptosis, when compared with control cells. Barzegar et al reported that DOX efficiently arrested cell division and stimulated apoptosis via DNA intercalation, generation of oxidizing moieties, binding to cellular membranes, and inhibition of topoisomerase II (Topo IIA) which is greatly expressed in S and G2/M phases [20].

Approaches based on making good use of natural products for cancer prevention and/or treatment have attracted a lot of attention in the past years. Garlic (Allium sativum) has been known for long for its medical uses. Multiple reports suggest that $A G E$ exerts anti-cancer effect with multiple cellular mechanisms such as induction of apoptosis, cell cycle arrest, and suppression of cell proliferation [11]. Inhibition of early and late stages of cancer by AGE leads to inhibition of tumour growth in many tissues like mammary gland, skin, colon, and gastric tissue [21].

The anticarcinogenic effect of AGE is attributed to its richness in organo-sulfur compounds such as allicin, S-allyl-cysteine, S-allo-mercaptocysteine, diallyl-trisulfide and diallyl-disulfide. Thus, AGE could be considered as a perfect sensitizer to the cytotoxic effect of DOX against breast cancer cells. In the present study, higher concentrations of AGE were more cytotoxic than the lower concentration. As reported by Pourzand et al, high intake of garlic is linked to decreased risk of breast cancer [21]. In the current study, MCF-7 cells treated with AGE alone at higher concentrations (50 and 93 $\mathrm{mg} / \mathrm{mL}$ ) showed a significant increase in apoptotic cells. Aged garlic extract (AGE) has been previously reported to induce dose-related cell cycle arrest, growth inhibition and apoptosis in many human cancer cell lines [22].

To understand the mechanism of interaction between DOX and AGE, apoptosis assay, cell cycle assay and DOX cellular uptake assay were performed. Apoptosis assay showed that DOXAGE combination significantly increased apoptotic cells, and significantly decreased the population of cells in G1/G0 phase, when compared with DOX alone. These results are in agreement with those of Zhang et al, who reported that SAMC derived from garlic effectively inhibited the growth of MCF-7 cells via stimulation of apoptosis and cell cycle arrest at G0/G1 phase. They also suggested that SAMCinduced apoptosis in MCF-7 (estrogendependent) and human hormone-independent breast cancer (MDA-MB-231) cells occurred through activation of the mitochondrial apoptotic pathway via upregulation of Bax, downregulation of Bcl-2 , and activation of caspase- 9 and caspase-3 [22].

In this study, the percentage of cell accumulation at $S$ phase was significantly decreased in combination treatment with DOX and highest concentration of AGE, when compared to the DOX alone. This finding is in agreement with that of Osman et al, who reported that resveratrol induced cell cycle arrest at $S$ phase, thereby exposing a high percentage of tumour cell population to DOX so that more cells underwent apoptosis and entered G0 phase [23]. The results were further strengthened by the rise in DOX cellular uptake following co-treatment with AGE in a concentration-related manner. There was progressive build-up of DOX in cells cotreated with DOX/AGE, which is consistent with exposing higher proportion of MCF-7 cells to DOX through cell accumulation in G0 phase. The rise in DOX MCF-7 uptake might be based on the inhibition of $\mathrm{P}-\mathrm{gp}$ and multidrug resistance which are involved in DOX absorption, distribution and elimination [24].

In the current study, Rh123 efflux was suppressed in DOX-treated MCF-7 cells in the presence of AGE. This finding is in agreement with that of Abdallah et al, who reported that resveratrol inhibited $\mathrm{P}$-gp, upon co-treatment with DOX, thereby triggering a rise in cellular uptake of DOX [24]. It has been reported that AGE suppressed the energy-dependent efflux pump of P-gp, thereby producing an augmented intracellular drug concentration and increasing cellular toxicity [25]. The extract prevented further absorption of DOX in cardiac tissue (cardio- 
protection), but it increased DOX concentration in tumour cells.

\section{CONCLUSION}

Aged garlic extract (AGE) has a chemosensitizing effect on DOX in human breast cancer cell line (MCF-7). This effect could be attributed to induction of apoptosis and enhanced intracellular DOX accumulation, the latter of which results from inhibition of P-gp activity.

\section{DECLARATIONS}

\section{Conflict of interest}

No conflict of interest is associated with this work.

\section{Contribution of authors}

We declare that this work was done by the authors named in this article and all liabilities pertaining to claims relating to the content of this article will be borne by the authors.

\section{Open Access}

This is an Open Access article that uses a funding model which does not charge readers or their institutions for access and distributed under the terms of the Creative Commons Attribution License (http://creativecommons.org/licenses/by/ 4.0) and the Budapest Open Access Initiative (http://www.budapestopenaccessinitiative.org/rea d), which permit unrestricted use, distribution, and reproduction in any medium, provided the original work is properly credited.

\section{REFERENCES}

1. American Cancer Society. Breast Cancer Facts \& Figures 2019-2020. Atlanta, 2019. Available at: https://www.cancer.org/content/dam/cancerorg/research/cancer-facts-and-statistics/breast-cancerfacts-and-figures/breast-cancer-facts-and-figures-20192020.pdf.

2. Ghoncheh M, Pournamdar Z, Salehiniya H. Incidence and mortality and epidemiology of breast cancer in the world. Asian Pac J Cancer Prev. 2016; 17(S3): 43-46. doi:10.7314/apjcp.2016.17. s3.43

3. Swift LP, Rephaeli A, Nudelman A, Phillips DR, Cutts $S M$. Doxorubicin-DNA adducts induce a nontopoisomerase II-mediated form of cell death. Cancer Res. 2006; 66(9): 4863-4871. doi: 10.1158/00085472. CAN-05-3410.

4. Alkreathy H, Damanhouri ZA, Ahmed N, Slevin M, Ali SS, Osman AM. Aged garlic extract protects against doxorubicin-induced cardiotoxicity in rats. Food Chem Toxicol. 2010; 48(3): 951-956. doi: 10.1016/j.fct.2010.01.005.

5. El-Saber BG, Magdy BA, Wasef LG, Elewa YH, A AlSagan A, El-Hack AM, Taha AE, M Abd-Elhakim Y, Devkota HP. Chemical constituents and pharmacological activities of garlic (Allium sativum L.): $A$ review. Nutrients. 2020; 12(3): $872 . \quad$ doi: 10.3390/nu12030872.

6. Banerjee SK, Mukherjee PK, Maulik SK. Garlic as an antioxidant: the good, the bad and the ugly. Phytother Res. 2003; 17(2): 97-106. doi: 10.1002/ptr.1281.

7. Nakagawa S, Masamoto $K$, Sumiyoshi $H$, Harada $H$. Acute toxicity test of garlic extract. J Toxicol Sci. 1984; 9(1): 57-60. doi: 10.2131/jts.9.57.

8. Miraghajani $M$, Rafie $N$, Hajianfar $H$, Larijani $B$, Azadbakht L. Aged Garlic and Cancer: A Systematic Review. Int J Prev Med. 2018; 9:84. doi: 10.4103/ijpvm.IJPVM_437_17

9. COMŞA Ş, Cimpean AM, Raica M. The story of MCF-7 breast cancer cell line: 40 years of experience in research. Anticancer Res. 2015; 35(6): 3147-3154.

10. Skehan P, Storeng R, Scudiero D, Monks A, McMahon J, Vistica D, Warren JT, Bokesch H, Kenney S, Boyd MR. New colorimetric cytotoxicity assay for anticancer-drug screening. J Natl Cancer Inst. 1990; 82(13): 1107-1112. doi: 10.1093/jnci/82.13.1107.

11. Šulić S, Panić L, Đikić I, Volarević S. Deregulation of cell growth and malignant transformation. Croat Med J. 2005 ;46(4): 622-638.

12. Van Engeland $M$, Nieland LJ, Ramaekers FC, Schutte B, Reutelingsperger CP. Annexin V-affinity assay: a review on an apoptosis detection system based on phosphatidylserine exposure. Cytometry. 1998; 31(1): 19.

13. Riganti C, Miraglia $E$, Viarisio D, Costamagna $C$, Pescarmona G, Ghigo D, Bosia A. Nitric oxide reverts the resistance to doxorubicin in human colon cancer cells by inhibiting the drug efflux. Cancer Res. 2005; 65(2): 516-525.

14. Kik K, Wasowska-Lukawska M, Oszczapowicz I, Szmigiero L. Cytotoxicity and cellular uptake of doxorubicin and its formamidine derivatives in HL6O sensitive and HL60/MX2 resistant cells. Anticancer Res. 2009; 29(4): 1429-1433.

15. Petriz J, Garcia-Lopez J. Flow cytometric analysis of $P$ glycoprotein function using rhodamine 123. Leukemia. 1997; 11(7): 1124-1130. doi: 10.1038/sj.leu.2400659.

16. García-Rocha $M$, Roca $A$, de la Iglesia $N$, Baba $O$, Fernández-Novell JM, Ferrer JC, Guinovart JJ. Intracellular distribution of glycogen synthase and glycogen in primary cultured rat hepatocytes. Biochem J. 2001; 357(1): 17-24. doi: 10.1042/02646021:3570017.

17. Jouan E, Le Vée M, Mayati A, Denizot C, Parmentier $Y$, Fardel O. Evaluation of P-glycoprotein inhibitory potential using a rhodamine 123 accumulation assay.

Trop J Pharm Res, August 2020; 19(8): 1675 
Pharmaceutics. 2016; 8(2): 12. doi: 10.3390/pharmaceutics8020012

18. Leonard RC, Williams S, Tulpule A, Levine AM, Oliveros S. Improving the therapeutic index of anthracycline chemotherapy: focus on liposomal doxorubicin (Myocet $^{\mathrm{TM}}$ ). Breast. 2009; 18(4): 218-224. doi: 10.1016/j.breast.2009.05.004.

19. Buranrat B, Suwannaloet W, Naowaboot J. Simvastatin potentiates doxorubicin activity against MCF 7 breast cancer cells. Oncol lett. 2017; 14(5): 6243-6250. doi: 10.3892/ol.2017.6783.

20. Barzegar E, Fouladdel S, Movahhed TK, Atashpour S, Ghahremani MH, Ostad SN, Azizi E. Effects of berberine on proliferation, cell cycle distribution and apoptosis of human breast cancer T47D and MCF7 cell lines. Iran J Basic Med Sci. 2015; 18(4): 334- 342. Available https://www.ncbi.n/m.nih.gov/pubmed/26019795.

21. Pourzand A, Tajaddini A, Pirouzpanah S, AsghariJafarabadi M, Samadi N, Ostadrahimi AR, Sanaat Z. Associations between dietary allium vegetables and risk of breast cancer: a hospital-based matched case-control study. J Breast Cancer. 2016; 19(3): 292-300. doi: 10.4048/jbc.2016.19.3.292.

22. Zhang $H$, Wang $K$, Lin $G$, Zhao Z. Antitumor mechanisms of S-allyl mercaptocysteine for breast cancer therapy. BMC Complement Altern Med. 2014; 14(1): 1-2. doi: 10.1186/1472-6882-14-270.

23. Osman AM, Bayoumi HM, Al-Harthi SE, Damanhouri ZA, ElShal MF. Modulation of doxorubicin cytotoxicity by resveratrol in a human breast cancer cell line. Cancer Cell Int. 2012; 12(1): 47. doi: 10.1186/1475-2867-12-47.

24. Abdallah HM, Al-Abd AM, El-Dine RS, El-Halawany AM. P-glycoprotein inhibitors of natural origin as potential tumor chemo-sensitizers: A review. J Adv Res. 2015; 6(1): 45-62. doi: 10.1016/j.jare.2014.11.008.

25. Osman AM, Mohamad MA, Abdel-Wahab AH, SayedAhmad MM. Modulation by verapamil of doxorubicin induced expression of multidrug resistance gene ( $\mathrm{mdr}$ 1/P-glycoprotein) in murine tumour cells. J Egypt Natl Cancer Inst. 2000; 12: 221-227. 